BOJAN B. DIMITRIJEVIĆ, viši naučni saradnik

Institut za savremenu istoriju

\title{
NASTANAK NACIONALNIH POKRETA OTPORA U SRBIJI 1941. GODINE*
}

\begin{abstract}
APSTRAKT: Članak se bavi nastankom i razvojem nacionalnih pokreta otpora u Srbiji tokom 1941. godine: delovima Jugoslovenske vojske pod komandom pukovnika Mihailovića koji je odbio kapitulaciju i četničke organizacije vojvode Pećanca. Takođe, i naporima Vlade generala Nedića da uspostavi vezu i koordiniše svoje oružane akcije sa tim grupama. Tekst je napisan na osnovu arhivske građe i literature.
\end{abstract}

Ključne reči: Nacionalni pokreti, Draža Mihailović, Ravna Gora, Kosta Pećanac

Posle kapitulacije Jugoslovenske vojske 17. aprila 1941, mnogi njeni pripadnici su izbegli zarobljavanje i odlazak u nemačke zarobljeničke logore. I pored celovitosti poraza JV, nemačka vojska nije uspela da pohvata sve begunce koji su se kretali po terenu sa oružjem ili bez njega, ali je računala na primenu oštrih mera kao preventivu. Većina njih je bila van komunikacija, po selima ili u njihovoj blizini, pojedinačno ili u manjim grupama. Jedan deo ovih ljudi se bojao povratka u prethodna boravišta odbijajući da živi uz okupatore, ili jednostavno plašeći se hapšenja. Stanovništvo ih je zvalo „šumski ljudi“ ili „šumci“, bez mnogo ulaženja u njihove pređašnje orijentacije.

Prvo su se čule glasine o ljudima Koste Pećanca (,četnicima“) i pukovnika Dragoljuba Mihailovića (,nepredata vojska“). Zatim, pominjali su general Ljubo Novaković i drugi oficiri. Pored njih terenom su se kretali i pojedini kriminalci ili bivši robijaši, koji su takođe nosili oružje.

\section{Nepredata vojska na Ravnoj Gori}

Posle aprilske katastrofe Jugoslovenske vojske, generalštabni pukovnik Dragoljub M. Mihailović stigao je iz Bosne sa svojim Brzim odredom 2. armije 11. maja na Ravnu Goru, gde je uspostavio sedište za organizovanje otpora u

${ }^{*}$ Rad je deo projekta Konflikti i krize - saradnja i razvoj u Srbiji i regionu u 19. i 20. veku (47030) koji finansira Ministarstvo prosvete i nauke Republike Srbije. 
okupiranoj otadžbini. Mihailović je bio veteran Balkanskih i Prvog svetskog rata. U vojnoj karijeri, koja je počela od upisa u Vojnu akademiju 1910. godine, prošao je niz trupnih i štabnih dužnosti, a u sam Aprilski rat 1941. ušao je kao načelnik operativnog odeljenja 2. armije. Ova armija je prošla mučan ratni put iz centralne Bosne, preko Slavonije i Posavine, da bi neslavno završila opet u predelima srednje Bosne, predajući se okupatoru i raspadajući se po nacionalnim šavovima. Niz događaja, kojima je bio svedok, uverio je pukovnika Mihailovića u nemogućnost otpora na terenu koji je pokrivala njegova armija. Stoga je na prve glasine o pregovorima o kapitulaciji rešio da sa vojskom kojom je raspolagao krene u Srbiju gde se nadao stabilnijem frontu. Inspirisan je bio očajnom situacijom na terenu kojim se kretao tih aprilskih dana, ali bez sumnje i svojim predratnim projektima dok je radio u Generalštabu na uputstvima za jedinice koje se nađu odsečene od svoje glavnine. ${ }^{1}$

Krećući se od Ševarlija kod Doboja ka Drini, grupa pukovnika Mihailovića saznala je vesti o definitivnoj kapitulaciji Kraljevine Jugoslavije. U svojim kasnijim izjavama Mihailović kaže da je po dolasku na Drinu odlučio da posle prelaska u Srbiju počne sa otporom okupatoru. Pre svega računao je na ljude u zapadnoj Srbiji, gde je nameravao da pokrene prve oružane akcije. Mihailovićev Brzi odred 2. armije je po dolasku na Ravnu Goru brojao 26-27 oficira, podoficira, vojnika i žandarma, i kao takav nije predstavljao nikakvu borbenu i vojnu vrednost, osim simbolične. Stoga je pukovnik Mihailović odlučio da se prvo sa svojim odredom smesti na sigurno mesto, gde ne bi bili izloženi pretnji od Nemaca, i sa kog bi mogao da u tišini uspostavlja organizaciju pokreta Siporaojvode Živojina Mišića, Aleksandar, bio je od prvog momenta uključen u organizaciju pokreta otpora. Dragoljub Mihailović i Aleksandar Mišić su bili bliski kućni prijatelji. Iako različitih karaktera i ponašanja, negovali su čvrsto prijateljstvo i posle Mišićevog penzionisanja. U momentu dolaska na Ravnu Goru, pukovnik Mihailović je odmah otišao kod svog prijatelja koji je u tom trenutku bio u Struganiku i izložio mu svoje planove. U prvim danima organizovanja pukovnik Mihailović poverio je majoru Mišiću organizatorsku i komandnu dužnost u rejonu Kolubare, severno od Valjeva. ${ }^{3}$

U političkom smislu, možda bi bilo bolje da je ustaničko središte izabrano na nekoj od lokacija na kojoj će biti ugrožen srpski narod, pre svega u Bosni i Hercegovini. „Da se Draža smestio u Herceg Bosni, nikad Tito ne bi održavao važne komunističke sastanke u Bihaću i krojio sudbinu naše zemlje u Jajcu“, jetko primećuje Ratko Parežanin. ${ }^{4}$ U vojnom smislu, izbor Ravne Gore za sedište bio je relativno dobar. Ova crvenozemljasta visoravan, koja će kasnije dati svoje ime čitavoj Mihailovićevoj vojsci i političkom pokretu, prostire se blizu nekoliko srpskih

\footnotetext{
${ }^{1}$ Бојан Димитријевић, Бенерал Михаиловић, Биографија I део, Београд 1996, 169-208.

${ }^{2}$ Исто, 209-237

${ }^{3}$ Исто, 163-164, 233-236.

${ }^{4}$ Ратко Парежанин, Други светски рат и Димтрије В. Љотић, Београд 2001, 409.
} 
varošica, pa i Beograda, a opet je bila vrlo nepristupačna za iznenadne posetioce. U tim uslovima grupa „nepredate vojske“ mogla je na miru da se konsoliduje. Glavni oslonac pukovnika Mihailovića bila su okolna sela Kačera, Kolubare, Valjeva, Takova, gde je saznanje o „nepredatoj vojsci“ raslo iz dana u dan. Prisustvo generalštabnog pukovnika na do tada pustoj i zabačenoj Ravnoj Gori, koji je nastavljao otpor sa snagama neodređene jačine (a koja je u razgovorima od usta do usta narastala u čitavu armiju), postalo je ubrzo poznato po čitavoj zapadnoj Srbiji. Već posle nekoliko nedelja od dolaska iz Bosne sedište pukovnika Mihailovića počeli su da obilaze različiti posetioci. Najveći deo njih bili su mlađi oficiri i podoficiri koji su se privučeni glasinama, ali i patriotskim nabojem i pomućenim osećanjima proisteklim iz aprilskog poraza, koji je zahtevao osvetu, pojavljivali na Ravnoj Gori i priključivali Mihailovićevoj organizaciji. Jedan deo onih koji su stizali na Ravnu Goru u tim danima od ranije su znali za pukovnika Mihailovića. To su bili njegovi bivši potčinjeni, slušaoci iz Vojne akademije, saborci iz prošlog rata, porodični prijatelji i njihova deca, ili oni koji su pak znali o njemu ponešto što su čuli od njegovih prijatelja. ${ }^{5}$

Mihailović je zadržao samo nekolicinu pridošlica, uvrstivši ih u svoju ravnogorsku družinu. Ostale je upućivao na rad u matični kraj da šire organizaciju otpora, zasnivajući je na striktnim uputstvima o tajnosti rada. Bezbednosni i ekonomski razlozi nisu omogućavali da se na Ravnoj Gori stvori snažnija ustanička formacija. Ubrzo su sela smeštena na levoj i desnoj strani od Ravne Gore postala zona u kojoj su krstarili Mihailovićevi organizatori i stvarali tanku strukturu budućeg pokreta otpora. Njihovi zadaci su bili da po selima popišu sva aktivna i rezervna vojna lica koja su izbegla kapitulaciju i odvođenje u zarobljeničke logore. Zatim, trebalo je pronaći veterane prošlih ratova, imućne seljake i druge ljude čija bi aktivnost pomogla organizaciju otpora; popisati ili sakupiti sakriveno oružje i vojnu opremu, napraviti nove spiskove regruta koje je po stasavanju trebalo uključiti u organizaciju, stvoriti obaveštajnu mrežu, širiti vesti koje bi podigle moral stanovništva drastično poljuljan porazom i raspadom Kraljevine. ${ }^{6}$ Zadatak koji su imali Mihailovićevi organizatori nije bio jednostavan. Seljaci, pod dubokim utiskom sloma i prepuni rezignacije, bili su odbojni i sumnjičavi prema oficirima koje su krivili za aprilski slom. Strah od Nemaca je takođe otežavao rad, jer je Vermaht bio nemilosrdan prema onima koji su zaticani sa oružjem. Pojava naoružanih razbojnika na terenu takođe je pogodovala nesigurnosti.

\section{Četnička organizacija vojvode Koste Pećanca}

O četničkoj organizaciji na čijem je čelu stajao vojvoda Kosta Pećanac čulo se najranije i znalo se još iz predratnih vremena. Njene podružnice bile su

\footnotetext{
${ }^{5}$ Lucien Karchmar, Draza Mihailovic and the Rise of the Cetnik Movement 1941/1942, Garland Publishing Inc, New York and London 1987, 82-84.

${ }^{6}$ Isto, 84 .
} 
prisutne u svim delovima Srbije i u svakom od njih se znalo ko su vodeći četnici. Ova organizacija gotovo da nije prekidala dejstva od početka rata, pa je to poslužilo nekima od njenih prvaka da kasnije ističu svoje ustaničko prvenstvo. Posle rata, na toj osnovi pojedini propartizanski istoričari su navodili da je ta organizacija „prva nacionalna oružana formacija u okupiranoj Srbiji““. ${ }^{7}$ Postojanje četničke organizacije Koste Pećanca i njena aktivnost na mobilizaciji i stvaranju odbora po selima čini sliku tadašnje Srbije znatno složenijom nego što je ona u istoriografiji i literaturi predstavljana. Tu sliku otežava znatan nedostatak arhivske građe za tu fazu postojanja četničkih snaga Koste Pećanca. ${ }^{8}$

Legendarno ime Koste Pećanca pominjalo se dosta u danima posle aprilskog sloma. Bez sumnje delovi njegove organizacije nastali su tokom rata u aprilu 1941. i deo je zadržao aktivan stav i narednih meseci, pogotovo u zoni gde je počeo arnautski ili bugarski teror nad srpskim stanovništvom. ${ }^{9}$ U periodu do 19. do 29. aprila, Pećanac je izdao nekoliko naređenja o postavljenjima pojedinaca za komandante četničkih odreda koje je trebalo formirati pod njihovom komandom. Cela ova aktivnost isključivo je bila vezana za jug Srbije: Kosanicu, Toplicu, Jablanicu, obode Kopaonika i okolne zone prema Kosovu. ${ }^{10}$ U kasnijim dokumentima pominje se nekoliko takvih odreda, koji su postojali i 1942. godine (Korvinski, Vlasotinački, Bruski, Vrnjački, Vučitrnski). ${ }^{11}$

Koje su bile kompetencije ove organizacije da krene u organizaciju otpora? Pećancu je dato ovlašćenje da formira oružane četničke odred u smislu naređenja ministra vojnog (36/41) i komandanta V armijske oblasti Vojske Kraljevine Jugoslavije (1816/41). Na ova naređenja Pećanac se redovno pozivao u svojim dekretima i objavama. ${ }^{12}$ Momčilo Pavlović u monografiji o Pećancu ukazuje da ova naredba do danas nije pronađena, ali da se može ,pretpostaviti da je postojala“. ${ }^{13}$ Ravnogorska vojna organizacija je tumačila to naređenje samo kao odobrenje za rad na teritoriji te oblasti, odnosno na jugu Srbije.

Ova gerilska organizacija imala je istu ciljnu grupu u stanovništvu kao i „,nepredata vojska“, pa je njena konkurencija u prvim danima otpora bila i te kako osetna za organizaciju pukovnika Mihailovića. Prepoznat kao četnički vojvoda iz Svetskog rata, Pećanac kao da je imao neku vrstu nepisanog prava da njemu gravitiraju svi koji su ostali na terenu i nisu se mirili sa okupacijom. Razumljivo, ako nisu bili komunisti. Tako su se u tim danima kapetan Keserović koji je bio u

\footnotetext{
${ }^{7}$ Драгољуб Петровић, Четничка организаиија Косте Пећанияа у окупираној Србији до почетка октобра 1941. године, ВИГ, бр. 2, 1968, 173-202.

${ }_{9}^{8}$ Ovo je kolega Dragoljub Petrović uočio još 1968. - Д. Петровић, н. н., 173-202.

${ }^{9}$ Момчило Павловић, Божица Младеновић, Коста Миловановић Пећанаи, Београд 2006, 167-171.

${ }^{10}$ Исто, 183.

${ }^{11}$ Arhiv Vojnoistorijskog instituta (AVII), Nedićeva arhiva (Nda), k. 33A, f. 12; Д. Петровић, н. н., 176

${ }^{12}$ Isto, f. 14, d. 23; Д. Петровић, н. н., 173,

${ }^{13}$ М. Павловић, Б. Младеновић, н. д., 173.
} 
zoni Kruševaca ili potpukovnik Milutin Radojević u rejonu Stalać-Žitkovac sa svojim ljudima priključili Pećancu, ${ }^{14}$ iako su bili aktivni oficiri. Tada nisu znali ni za kakvu drugu organizaciju otpora. U uslovima prelaska na četnički oblik borbe, aktivnom oficiru je bilo normalno da pristupi četničkoj organizaciji.

$\mathrm{U}$ ovom periodu, na terenu je bio aktivan i raniji komandant Komskog odreda Jugoslovenske vojske, general Ljubo Novaković. On se posle Aprilskog rata sklonio u selo Lelić, sa dva niža oficira i određenom količinom novca. Sa grupom svojih pratilaca potom se pojavio na Ravnoj Gori. Tu je Novaković boravio neko vreme, sve dok nije oteran posle jednog problematičnog incidenta koji je izazvao. Nešto kasnije otišao je sa pratnjom na Rudnik gde je ušao u organizaciju Koste Pećanca, koji ga je prihvatio i dodelio mu titulu vojvode šumadijskog.

Okupljajući ljude po rodnoj Toplici, Pećanac još uvek nije pomišljao na bilo kakav ustanički poduhvat, jer mu je katastrofalan ishod Topličkog ustanka 1917. u kome je i sam uzeo učešća morao biti na umu. Stoga je posle aprila 1941. samo naimenovao četničke vojvode u svim krajevima Srbije. Njihova regrutna baza bili su članovi četničkih udruženja. Smatrajući sebe ekskluzivnim vođom nove četničke akcije, Pećanac je odbijao kontakte sa svim emisarima koje su upućivali pukovnik Mihailović ili general Ljuba Novaković.

Nemačke vojne vlasti su zazirale od četnika i njihove pojave, iako sporadične, u prvim danima okupacije. Komunisti još nisu bili protivnici, a od članova četničkih organizacija se moglo očekivati da spremaju akciju. „Moglo bi se reći da je okupator sve do 22. juna rigoroznije mere sprovodio prema četnicima nego prema komunistima“, zaključio je propartizanski istoričar Dragoljub Petrović još 1968. godine. ${ }^{15}$

Koristeći iste simbole, zalažući se za istu ideju, a uglavnom se izgledom ne razlikujući od Mihailovićevih ljudi, organizacija četnika Koste Pećanca ne samo da je nudila još jednu alternativu stanovništvu već je i povećala konfuziju na terenu. U toj situaciji razni kriminalci i probisveti koristili su istu simboliku i za svoj račun su krstarili terenom i vršili razbojništva. ${ }^{16}$

$\mathrm{Na}$ Vidovdan 28. juna 1941, Pećanac je naredio ljudstvu da položi zakletvu, što je i obavljeno na istaknutim mestima na terenu. Istog dana on je kao ,predsednik Glavnog odbora i komandant svih četničkih odreda“ objavio naredbu u kojoj se navodi da se nemačke i italijanske snage ne smeju napadati ili ubijati sve dok se pristojno i čovečanski ponašaju prema srpskom narodu. ${ }^{17}$ Do tog trenutka Pećanac nije davao vojvodske titule. Svega nekoliko njegovih vojvoda nosilo je te titule iz vremena Prvog svetskog rata (Mašan Đurović - vojvoda ibarski, Stojan - vojvoda vrnjački, Nikčević - vojvoda kosmajski). Na Vidovdan su

${ }^{14}$ Јелена Ђиновски, Организаиија Косте Пећанца у крушевачком округу, јун 1941 децембар 1942, Расински анали, 1/2003, 225-230; Д. Петровић, н. н., 178.

${ }^{15}$ Д. Петровић, н. н., 181.

${ }^{16}$ L. Karchmar, $n$. d., 108-112.

${ }^{17}$ AVII, Nda, k. 33, f. 13, dok. 3; Д. Петровић, н. н., 181; М. Павловић, Б. Младеновић, н. д., 184. 
dodeljene nove titule, kao i preciznije naznačeni delovi Srbije u kojima su te vojvode trebale da četuju i organizuju četnike. ${ }^{18}$

Više izvora (osim arhivskih, tu je i pisanje Rade Drainca) potvrđuju da je raspoloženje u redovima i vrhu Pećančeve organizacije bilo patriotsko, borbeno, pa čak i rusofilsko do sredine leta 1941, kao i da je ta organizacija nameravala da se intenzivnije angažuje u borbi protiv arnautskih grupa nego protiv ostalih na terenu. U isto vreme Pećančeve organizacije počinju da niču i u ostalim delovima Srbije. To se često dešavalo paralelno sa ravnogorskim organizacijama, zahvatajući mnogo više teritorije, ako je suditi po titulama i broju vojvoda sa kojima Pećanac komunicira leta 1941. godine. Primetno je, međutim, da su njegovi organizatori na terenu često imali znatno manje ljudi od ravnogorskih organizatora: tek po nekoliko njih, dok su se ostali vodili na papiru. ${ }^{19}$

Miloš Mladenović, jedan od učesnika ratnih događaja iz Toplice, slikovito opisuje pojavu Pećančevih ljudi na terenu svoga kraja.

„U to vreme Pećančevi četnici zalazili (su) po svim selima i tražili državnu opremu i oružje a uz to pretresali sve odreda i uzimali sve što im se svidelo. Onaj ko bi se tome usprotivio, i odbio da dâ, bio bi premlaćen kao pas. Zbog toga jedan dobar broj ljudi, da bi zaštitili sebe i svoje, organizovali su se u takozvane „mesne četnike“. To je bio jedini način da se sačuvaju od Pećančevih četnika, koji su silazili iz njegovog glavnog štaba na Sokolovici planini. Ti četnici koji su silazili iz „glavnog štaba“, bili su mahom izbeglice sa Kosova i iz Metohije, i sve što su ukrali i opljačkali nosili su svojim novozasnovanim kućama ili sklanjali kod raznih domaćina. Izvesne izbeglice, koji su se svrstali u Pećančeve četnike, nisu bili pošteni izgnanici kao što su bili Srbi preko Dunava i Drine ili Slovenci iz Slovenije, već dobrim delom siledžije i pljačkaši sa Kosova i Metohije, koji su godinama iza Prvog svetskog rata otimali od muslimanskog i šiptarskog stanovništva sve što su hteli, natresali se i šamarali ljude ni za šta ili zbog nasilja koje je car Murat na Kosovu počinio. Takvi ljudi su u novoj situaciji bežali od osvete, i sad im nanovo sa Kostinom objavom džepu i oružjem u ruci zapalo da tobože održavaju red kod nas u Toplici, pa su na sopstveni narod primenili ono isto kako su uređivali „Turke“, po Kosovu. Pećanac, iako je znao, a možda i gledao sve to, ćutao je i unapređivao ih, kako bi vezao koga uza se, jer ga je ceo narod prozreo i omrzao usled saradnje sa okupatorskim vlastima. Ako se protivu njih nije hteo boriti, nije morao ni sarađivati, već ćutati u nekom selu. Za njega je bar imalo dosta mesta u Toplici. Pećanac je u Toplici razočarao sve i od čestitih domaćina sa njim niko nije hteo poći kao što su nekad ljudi polazili sa Kostom Vojinovićem, čijim se perjem Pećanac po Jugoslaviji kitio. To je bio razlog da je Pećanac davao vojvodske titule svakome ko bi hteo da ih primi... Teško je tada bilo naći domaćina kome Pećančevi pljačkaši nisu prečistili sve iz kuće. ‘20

${ }^{18}$ AVII, Nda, k. 33, f. 13, dok. 3.

${ }^{19}$ Isto; Д. Петровић, н. н., 183.

${ }^{20}$ Милош Младеновић, Лажни идоли и варљиви идеали, прир. Иван Ивановић, Београд 2004, 69-70. 
Izlazak komunista na teren posle 22. juna 1941, njihova oružana akcija i nemačke represalije koje su usledile u severozapadnoj Srbiji, uključiće i Pećanca u ratni vrtlog na srpskom prostoru.

\section{Žandarmerija i vojno-četnički odredi pukovnika Mihailovića}

Komunisti su se nadali da će podizanjem bune u Srbiji odvući deo snaga Vermahta sa sovjetskog ratišta koje je postalo realnost posle nemačkog napada na SSSR 22. juna 1941. Ovom naivnom i pogubnom verovanju bio je u početku protivan i pukovnik Mihailović, koji je svoj stav saopštio pojedinim komunističkim emisarima u kontaktu sa njima. Znajući da se sa slabim ustaničkim snagama ne može krenuti u uspešan ustanak na Nemce, on je sugerisao komunistima da se sačeka poboljšanje opšte situacije na svetskim ratištima pa tek onda da se ide u boj. Tako suprotstavljeno viđenje ratne realnosti prouzrokovalo je snažnu sumnjičavost između dve organizacije.

Na drugoj strani, pukovnik Mihailović je aktivno nastojao da uspostavi veze sa okolnim žandarmerijskim stanicama i ostacima lokalnog aparata, apelujući na nacionalnu i patriotsku svest koju je trebalo ispoljiti u tim teškim danima. Žandarmi su posebno bili od važnosti kao jedini Srbi kojima je u tom periodu bilo dozvoljeno da nose naoružanje. ${ }^{21}$ Jedan deo njih je bio uključen u ilegalnu organizaciju otpora, kako pokazuje struktura ravnogorskih organizatora iz 1941. u pojedinim krajevima. $^{22}$

Vrhu srpske žandarmerije je već tada postalo jasno da pojedine njene snage u zapadnoj Srbiji i Šumadiji održavaju vezu sa ustaničkim štabom na Ravnoj Gori i da u principu svoje aktivnosti usklađuju sa njima. Posle nekoliko sastanka sa komunistima, jedan od Mihailovićevih ljudi, poručnik Neško Nedić, stupio je u kontakt sa predstavnicima komesarske vlasti u Mionici, gde je 14. jula 1941. održan sastanak između njega i sreskog načelnika, dvojice žandarmerijskih oficira i predstavnika Komesarijata u Beogradu. Poručnik Nedić je izvestio ovu delegaciju da ljudi pukovnika Mihailovića nemaju nikakve veze sa terorističkim akcijama koje su započeli komunisti. Pored toga, dao je prisutnima i neke podatke o komunističkim grupama - verovatno onim koje je sretao po terenu i sa kojima su vođeni pregovori. ${ }^{23}$ Mada ranija istoriografija na temelju ovih razgovora

${ }^{21}$ Кьига о Дражи, ур. Радоје Кнежевић, том I, Виндзор 1956; L. Karchmar, n. d., 85.

22 Горан Давидовић, Милош Тимотијевић, Затмњена прошлост (историја равногорача чачанског краја) књига 1, Чачак-Краљево $2002,124$.

${ }^{23} \mathrm{O}$ tome govori i sećanje pukovnika Jova Trišića, koji je u Mionicu došao sa Ilijom Paranosom i žandarmerijskim potpukovnikom Milanom Cvetkovićem. „Još takoreći nismo ni seli, kad mi vodnik mioničkog žandarmerijskog voda saopšti da me u vodnoj kancelariji očekuju neki oficiri iz Dražinog štaba. Tamo sam zatekao poručnika Neška Nedića i rez. poručnika Voju Popovića. Obojica su bili odeveni u lepim novim narodnim nošnjama. Izjavili su mi da su poslati da prisustvuju sastanku i vide se sa mnom. Dogovorili smo se da ja sutradan odem u Struganik na sastanak s Dražom. U pratnji dvojice-trojice oficira odem u Struganik gde nas je dočekao major A. Mišić. Draža je bio sprečen da dođe. Sastanak smo održali u stanu udove pok. vojvode Mišića...". - Јован 
imputira neiskrenost Mihailovićevoj organizaciji koja je istovremeno pregovarala i sa komunističkom organizacijom, čini se da su ovakvi razgovori Mihailovićevih ljudi sa organima vlasti bili nužni u momentu kada se na tih i neupadljiv način stvarala ravnogorska organizacija otpora. Talas komunističkih akcija na terenu Srbije mogao je samo da šteti Mihailovićevoj organizaciji, jer su zbog tih akcija u pokret bile stavljene nemačke jedinice. Njihovo prisustvo na terenu nimalo nije bilo dobrodošlo za razvoj Mihailovićevog pokreta otpora. Napadi na žandarmerijske stanice i paljevine opštinskih i seoskih arhiva takođe su nanosili štetu Mihailovićevoj organizaciji, jer su žandarmi smatrani za potencijalne učesnike otpora, a mnogi su i bili na raznolike načine uključeni u organizaciju pukovnika Mihailovića.

Istoričar Lisjen Karčmar je odlično primetio da je kod partizana iz trena $\mathrm{u}$ tren rasla svojevrsna frustracija, prouzrokovana činjenicom da su oni morali da tretiraju pukovnika Mihailovića kao ravnog sebi. Po njihovom mišljenju Mihailović je bio običan vođa organizacije uglavnom ograničene na zapadnu Srbiju, dok su svoj pokret videli kao superiorniji jer je imao razgranatu mrežu po celoj državi. Uz to, višegodišnja konspirativna, politička i propagandna aktivnost davala je komunistima dodatnu nadmenost. Istorijat pregovora govori da su komunisti tokom leta i rane jeseni 1941. godine posmatrali organizaciju pukovnika Mihailovića kao minoran i lokalni fenomen sa kojim se moglo pregovarati na nivou lokalnih komandanata odreda. Takva situacija, međutim, ubrzo će se izmeniti rastom i širenjem Mihailovićeve organizacije otpora. Mihailoviću su postepeno upućivani, po funkciji, sve viši komunistički prvaci da bi se na kraju u pregovore sa njim morao da upusti i sam generalni sekretar Komunističke partije Jugoslavije - Josip Broz Tito. $^{24}$

Partizane je mogla da čini ogorčenim i oštrim u pregovorima još jedna činjenica. Oni nisu rado gledali na uključivanje žandarma u Mihailovićevu organizaciju i njihovo stalno prisustvo u štabu na Ravnoj Gori, jer su prema žandarima gajili mržnju još iz doba ilegalnog partijskog rada. O tome piše i Dragojlo Dudić: „Odgovorili smo na adresu pukovnika Mihailovića: da smo prilikom razoružanja (25. avgusta - prim. B. D.) rekli da ćemo im vratiti oružje samo ako pukovnik Mihailović pošalje svoje ljude, jer mi žandarmima ne verujemo. ${ }^{625}$ Mnogi žandarmi koji su prilazili Mihailoviću bili su takođe odbojni prema komunistima, a takav stav se pojačavao serijom napada partizana na žandarmerijske stanice. Njihova mržnja prema komunistima bila je jača nego kod aktivnih oficira, a nekoliko žandara će kasnije postati strah i trepet za partizane.

П. Тришић, Први дани рата у јужној Србији и прилажење покрету Драже Михаиловића, Гласник Српско историско-културног друштва „Његош“, свеска десета, децембар 1962, 87.

${ }^{24}$ L. Karchmar, n. d., 189-194.

${ }^{25}$ Драгојло Дудић, Дневник 1941, Београд 1988, 105. 


\section{Pokušaj dogovora generala Nedića sa pukovnikom Mihailovićem}

Odmah po obrazovanju Vlade, predsednik Nedić je prvih dana septembra 1941. dao nalog šefu svog kabineta da stupi u vezu sa pukovnikom Mihailovićem kako bi mu uputio hitnu poruku. Prema Stanislavu Krakovu, pismo je bilo kratko i oprezno. Nedić je zahtevao od Mihailovića da se sretnu u Beogradu i usklade svoju akciju. Mihailović je kasnije izjavio da nije otišao na sastanak, ali je u Beograd uputio svoje saradnike, majora Mišića i potpukovnika Pavlovića. U toku razgovora sa izaslanicima pukovnika Mihailovića, Nedić je govorio o smrtnoj opasnosti koja se nadvila nad srpskim narodom i Srbijom, koju su Nemci nameravali da podele između neprijateljskih suseda, ističući da je to presudno uticalo da se on prihvati vlasti. Opasnost po Srbiju nije prestajala zbog komunističke akcije ali i zbog eksplozije opštenarodnog ustanka, kojem je kao vođa figurirao pukovnik Mihailović, ocenio je general Nedić. ${ }^{26}$

General Nedić je smatrao da je za opstanak srpskog naroda neophodno da se Mihailović sa svim odredima odmah prebaci na teritoriju Bosne i Hercegovine, organizuje borbu protiv ustaškog terora i tako pruži zaštitu srpskom življu. $\mathrm{Na}$ tom terenu je trebalo da organizuje srpski nacionalni element u okviru svojih vojnih formacija i stvori moćnu osnovu za opštu akciju kada za nju dođe povoljan momenat. Za to vreme Nedić bi sa svojim trupama očistio Srbiju od komunizma koji je najveća opasnost za srpski narod u sadašnjosti i još više u budućnosti, $i$ to upravo onda kada Nemci budu izgubili rat, jer se komunisti ne bore za slobodu Jugoslavije „već za njeno potpadanje pod Sovjete“. Nedić je ponudio da finansijski i oružjem pomogne takvu Mihailovićevu akciju, u okviru svog dogovora sa Nemcima. Sličnu poruku, po majoru Paloševiću, iz manastira Ljubostinje poslao je i episkop Nikolaj Velimirović.

Drugi Nedićev predlog bio je da se bar akcija protiv komunista koordinira na neki način. Nedić je predviđao da njegova tri oružana odreda koja su se zaputila u severozapadnu Srbiju uhvate vezu sa ,četničkim odredima koji su pod komandom generalštabnog pukovnika g. Draže Mihailovića“ i na toj liniji sačekaju naredbu za dalja dejstva. ${ }^{27}$ Kako objašnjava pukovnik Trišić, „đeneral Panta Draškić (ministar rada, ali sa zadatkom da vodi računa o oružanim snagama) bio je razradio plan za borbu protiv komunista u kome je predvideo i snage Draže Mihailovića, ali bez prethodnog znanja i odobrenja Dražinog ${ }^{428}$ Naime, Draškić je ovaj plan napravio sa nekoliko vodećih ličnosti Ministarstva unutrašnjih poslova ( ̌̌efom javne bezbednosti Cekom Đorđevićem, višim savetnikom Aleksandrom Joksićem, pukovnikom Slavkom Jakovljevićem, šefom Draškovićevog kabineta), ali i sa komandantom žandarmerije Trišićem. Međutim, Trišić

${ }^{26}$ Станислав Краков, Генерал Милан Недић, Минхен 1963, 151-153; Мирко Бојић, Југославенски народни покрет „,ЗБОР“, 1935-1945, један критички приказ, Београд 1996, 177.

${ }^{27}$ С. Краков, н. д., књ. 1, 160.

${ }^{28}$ J. Тришић, н. н., 79-90. 
je plan poslao Mihailoviću po poručniku Pipanu i žandarmerijskom potpukovniku Olujeviću. On sam nije mogao da krene, jer je u to vreme predavao dužnost generalu Radovanoviću. Partizani su, međutim, kod Ljiga uspeli da zarobe auto u kome su bili Pipan i Olujević. Potpukovnika Olujevića su streljali, dok su poručnik Pipan i šofer uspeli da im pobegnu. Plan je tako bio izgubljen, a čitava stvar dekonspirisana. ${ }^{29}$

Na Ravnoj Gori, predlog predsednika Vlade generala Nedića nije ozbiljno razmatran. Bilo je više podsmeha i ocena o Nedićevoj ,izdaji“ nego stvarnog pokušaja da se definiše dublja nacionalna strategija. Žaleći se kasnije zbog Mihailovićevog ćutanja na ovakve konstruktivne predloge, general Nedić je ukazao na njegovu okolinu (pre svega na Dragišu Vasića) pod čijim je uticajem četnički vođa odbacio njegov plan. U svom objašnjenju Nedić je tom prilikom uzeo u obzir i Mihailovićevu ljutnju što ga je on pre rata, kao pukovnika, kaznio sa 30 dana pritvora. U svakom slučaju, tako je propuštena prilika da se usaglasi nacionalni i borbeni elemenat na celom prostoru srpstva. Tada je, kako se čini, učinjena sudbonosna greška, a komunistima dat zamah da svoju glavnu bazu formiraju na području srpskih krajeva van matice Srbije. ${ }^{30}$

Umesto dogovora Nedić-Mihailović, na pomolu je bio savez Tito-Mihailović. Njih dvojica su se 19. septembra 1941. sastali u kući majora Mišića u Struganiku, radi dogovora o zajedničkoj ustaničkoj akciji. ${ }^{31}$

\section{Stav Pećančevih četnika prema ustanku}

Vlada generala Nedića takođe je započela akciju radi koordinacije sa snagama vojvode Pećanca. Nasuprot pukovniku Mihailoviću i njegovim vojnočetničkim snagama koje su sa komunistima već učestvovale u ustanku, Kosta Pećanac je odlučio da se suprotstavi komunistima.

${ }^{29}$ Боривоје М. Карапанџић, Грађански рат у Србији, Београд 1993, 102-103. - Sam pukovnik Trišić je kasnije bio uhapšen i od Nemaca upućen u zarobljeništvo. Stanislav Krakov objašnjava da je na terenu kod žandarma koji je bio uhvaćen kao pripadnik ravnogorske organizacije nađena legitimacija sa potpisom pomoćnika komandanta žandarmerije, pukovnika Trišića. Gestapo je, nastojeći da izbegne hapšenje visokog službenika Vlade, naložio Specijalnoj policiji da diskretno uhapsi Trišića. Trišić je uhapšen u prisustvu generala Radovanovića, a prilikom pretresa njegove kancelarije nađena je velika količina praznih legitimacija, spiskovi sa 1.200 imena saradnika ravnogorske organizacije i drugi kompromitujući materijal, iz koga se videlo da Trišić održava aktivnu vezu sa Mihailovićevom organizacijom. Šef specijalne policije Ilija Paranos je izbegao da o ovome obavesti svog šefa Dragog Jovanovića, već je odmah tražio prijem kod generala Nedića. Odlučeno je da se sav kompromitujući materijal uništi, ali je sam čin da je bio uhvaćen u ilegalnoj aktivnosti bio dovoljan da Gestapo odredi Trišića za streljanje. Tek posle odlaska generala Nedića do generala Bemea ta odluka je preinačena i Trišić je upućen u zarobljeništvo. Sam Nedić je bio kivan na pukovnika Trišića, jer mu je svojom neopreznošću pričinio velike teškoće. - Станислав Краков, Генерал Милан Недић, књ. 1, Београд 1995, 267-268.

${ }^{30}$ Бојан Димитријевић, Коста Николић, Бенерал Михаиловић. Биографија, Београд 2000, 163-168.

${ }^{31}$ М. Бојић, н. д., 177. 
Tokom leta 1941, u južnoj i severoistočnoj Srbiji Pećančeve grupe su imale kontakte sa komunističkim grupama na terenu, pa je jedan broj njih bio raspoložen za međusobnu saradnju. ${ }^{32}$ Međutim, u vreme obrazovanja Srpske vlade krajem avgusta 1941, vojvoda Pećanac se definitivno okrenuo protiv ustanika. Prema pisanju savremenika, u tome je određenu ulogu odigrao i Dimitrije Ljotić. On je uputio Kosti Pećancu zajedničkog poznanika Zorana Vukovića, a ovaj je sa vojvodom Blaškom Mihajlovićem izneo Ljotićevo viđenje situacije i želju da Pećanac priđe Vladi koja je trebalo da bude obnarodovana za koji dan. ${ }^{33}$

U drugoj polovini avgusta usledila je preko drugih ljudi akcija nemačkih vlasti i srpske komesarske uprave prema Pećancu, sa idejom da se ogradi od komunističke akcije koja je već na terenu prouzrokovala ubijanja žandarma i nemačkih vojnika, drastične represalije u znak odmazde, kao i razaranja imovine od malog značaja za nemačku vojnu silu. To okretanje od relativno tolerantnog stava do protivljenja komunističkoj akciji desilo se u periodu od 24. do 27. avgusta. U početnim stavovima Pećanac je prilično nerealno nastupio sa zahtevom da se njemu i njegovim snagama prepusti uprava, naoružanje pa čak i žandarmerija, a da Nemci napuste Srbiju, osim velikih garnizona i prava prolaza. Usledio je proglas od 27. avgusta, naslovljen „Proglas dragom narodu“, prepun prejakih reči i preterivanja kada su Pećančeve moći bile u pitanju. „Svojim autoritetom uspeo sam a po želji celog našeg naroda primio sam se svete dužnosti da u našoj zemlji zavedem red to jest branim živote našeg naroda... Odgovornost koju ja u ovim preteškim danima primam na sebe velika je... rešio sam da Vas sve pozovem pod svetu četničku zastavu...“ Pećanac je „naredio“ da se svi koji su pod oružjem a nisu u njegovoj organizaciji vrate u narednih osam dana svojim kućama i redovnom poslu, odnosno da mogu odmah stupiti u njegove redove. U proglasu je ukazao da je pod pretnjom smrti zabranio napade na državnu i okupatorovu imovinu. ${ }^{34}$

Potom, Pećanac je krenuo ka Bukulji gde je 28. avgusta trebalo da se sastanu sve uticajne ličnosti njegove organizacije. Usput je njega i njegovu pranju razoružao komandant nemačkog bataljona iz Prokuplja i preteći držao uza zid, sve dok iz Beograda hitno nije doleteo oficir koji je razjasnio ko su i gde idu Pećanac i njegovi pratioci. Na sastanku na Bukulji, u prisustvu oko 300 delegata, Pećančevi stavovi su gotovo jednoglasno prihvaćeni. ${ }^{35}$

Kombinacijom patetičnih reči u „Proglasu“ Pećanac je postigao suprotan efekat od željenog. Njegove ideje da u Srbiji on treba da odlučuje o pokretu otpora bile su nerealne, i to u trenutku kada je ustanak bio pred eksplozijom u zapadnoj Srbiji i drugde. Neki od njegovih ljudi odmah su se suprotstavili ovakvom stavu. Štaviše, pojedini njegovi komandanti / vojvode počeli su da prelaze na stranu vojno-četničkih odreda pukovnika Mihailovića i da se uključuju u ustanič-

${ }^{32}$ Д. Петровић, н. н., 185.

${ }^{33}$ J. Томић, Четничка организација Косте Пећанца у окупираној Србији, Записи из добровољачке борбе 5, Минхен 1955, 7.

${ }_{35}^{34}$ AVII, Nda, k. 33, f. 11, d. 5.

${ }^{35}$ J. Томић, н. н., 7-13. 
ke akcije. Drugi, pak, nastavili su rad na terenu, ali nisu napadali grupe drugih organizacija. ${ }^{36}$

U poslednjoj nedelji avgusta, Pećančeve snage imale su sukobe sa albanskim grupama na prostoru od Tulara do Prepolca, kao odgovor na njihove ranije upade sa prostora Kosova. Zbog ovoga događaja, Pećanac je 8. septembra smenio komandanta Jablaničkog četničkog odreda Krstu Mihajlovića. Ovaj potom, sa najvećim delom svog ljudstva, kreće u akciju iz Medveđe 16. septembra i zauzima prostor Lebana i okoline od 17. septembra nadalje, ugrožavajući Leskovac. U tim danima Pećanac vodi živu prepisku sa Mihajlovićem i drugim vojvodama, koja pokazuje nemoć starog vojvode da kontroliše deo svoje organizacije, kao i nepriličan verbalizam, pun neostvarenih pretnji neposlušnom Mihajloviću. ${ }^{37}$

Posle formiranja Nedićeve Vlade i njenih oružanih snaga usledio je period kada se u Vladi i kod nemačkih vojnoupravnih organa ozbiljno počelo računati na Pećančeve snage. Kako nemački izvori navode: „... prema svim vestima kojima raspolažemo treba smatrati da su četničke formacije Koste Pećanca zauzele potpuno lojalan stav prema nemačkim okupacionim snagama." Jedan odred Koste Pećanca, kako je navedeno, napao je između 7. i 9. septembra „u planinama zapadno od Lebana jednu komunističku bandu“ i naneo joj značajne gubitke. Nemci su, međutim, imali drugi problem na terenu sa ovim snagama: „kao četničke formacije izdaju (se) i druge grupe koje ne pripadaju organizaciji Koste Pećanca“. Trebalo je u „sumnjivim slučajevima“ uvek tražiti objašnjenje od strane lokalne feldkomandanture. Naređenjem Feldkomandanture 809 u Nišu od 11. septembra izdate su smernice za postupak sa ljudstvom Pećančevih četničkih snaga. Problem je prevashodno bio u činjenici da je moglo doći (ili je već dolazilo) do hapšenja naoružanih ljudi, koji nisu mogli da odmah dokažu pripadnost, budući da je trebalo vremena da se obrasci legitimacija izrade i distribuiraju preko nemačkih ili srpskih organa ovim jedinicama. Regulisan je postupak sa ovim licima: „Iz usmeno saopštenih prinudnih razloga sa ovakvim uhapšenim licima, sve dotle dok postoji verovatnoća da se radi o četničkom ljudstvu, ophoditi se u svakom pogledu pristojno. Ukoliko se ispostavi da su podaci neistiniti, odbaciti svake obzire." Takođe je regulisano da ukoliko se kod određenog lica pronađe oružje kod kuće, a on izjavi da pripada organizaciji Koste Pećanca, onda se do završene provere trebalo „uzdržati od spaljivanja kuće“. Određene feldkomandanture su bile odredile svoje ljude za vezu. Tako je niška FK odredila untreštrumfirera Engelmana, koji je imao neprekidnu vezu sa ovim snagama na teritoriji FK. ${ }^{38}$

Posle sastanka sa Pećancem 15. septembra u Kuršumliji, dvojica predstavnika nemačkih oružanih snaga (poručnik Jening i unteršturmfirer Engelman) uverila su ga da je potrebno da dođe u Beograd radi dogovora o saradnji sa nemačkim organima i organima srpske vlade. Oni su potom preko Niša stigli u Be-

\footnotetext{
${ }^{36}$ Б. Карапанџић, н. д., 45-46; Обнова, 27. август 1941; L. Karchmar, n. d., 108-112.

${ }^{37}$ М. Павловић, Б. Младеновић, н. д., 219.

${ }^{38}$ Zbornik 12-1, 379-380.
} 
ograd. Pećanac je za opsežnije angažovanje svojih snaga tražio veću slobodu kretanja, proširenje organizacije ali i obezbeđivanje južne srpske granice. ${ }^{39}$

Komanda Srbije je 16. septembra 1941. svim svojim sastavima dostavila informaciju da se na području jugoistočne Srbije, odnosno Feldkomandanture u Nišu, nalaze ,nacionalne srpske bande Koste Pećanca“. Navedeno je da on stoji iza Nedićeve vlade sa svojim snagama, kao i da želi da Srbiju sačuva od građanskog rata. Feldkomandantura u Nišu je dozvolila nošenje oružja ovim snagama. „Oružje se, međutim, mora otvoreno nositi. Pripadnici Koste Pećanca treba da se što je moguće više uniformišu i imaju legitimacije pomoću kojih se legitimišu kao pripadnici grupa Koste Pećanca. Oni predstavljaju jedine četnike koji su priznati. Oni žele da prihvate borbu protiv komunista, navodno su se u pojedinim slučajevima borili protiv komunista." U ustaničkoj oblasti centralne i zapadne Srbije nalaze se ,bande koje se delimično takođe nazivaju četnicima, ali koje se nisu potčinile niti vladi niti Kosti Pećancu“. Nemci su zaključili da „ove bande rade zajednički sa komunistima i otvoreno sa oružjem u ruci nastupaju protiv nas kao neprijatelji." Pored ostalih opažanja o ustaničkim razlikama, taktici i drugim pitanjima ukazano je da se ,trupnim jedinicama mora od sada jasno staviti do znanja da je u ovom rejonu svaki Srbin (osim žandarma i finansijske straže) koji se nađe sa oružjem u ruci ili koji podržava komunističke i druge bande naš neprijatelj i da ga treba uništiti. “"

Prema nemačkim svedočenjima, između komandanta Srbije generala Danklemana i komandanta Više komande 65 generala Badera postojala su „oštra razmimoilaženja po pitanju nove srpske vlade i upotrebe srpskih snaga za borbu protiv komunista. Komandant Srbije imao je puno poverenje u Nedićevu vladu kao i četničke odrede pod komandom pukovnika Pećanca (tako je označen u dokumentu). Pukovnik Pećanac je preko posrednika ponudio da se sa svojim snagama bori protiv komunista. Pregovori koji su posle toga vođeni između komandanta (Srbije), nove srpske vlade i četnika doveli su do sporazuma, prema kome k-dant priznaje četnike, i njima daje pravo regrutacije i da se javno pojavljuju naoružani. Četnici su se sa svoje strane obavezali na borbu protiv komunista." U tu svrhu stavljeno je od komandanta Srbije Vladi na raspolaganje 15.00 puška i veći broj mitraljeza.

„Kod Više komande 65 mišljenja su da odluka komandanta Srbije da za razbijanje komunističkih bandi koristi srpsku vladu i četnike, može imati za posledicu dve velike opasnosti: da se četnici povežu sa komunistima i da ubrzo, novoformirani i organizovani, istupe protivu nemačkih okupacionih jedinica, i drugo, da srpska vlada, uspostavljajući pomoću četnika red u zemlji, ujedno formira stajaću vojsku, tako da nemačka okupaciona uprava mora uvek da računa sa opasnim ustankom a da mu ne može blagovremeno da stane na put, pošto će vlada $\mathrm{i}$

\footnotetext{
${ }^{39}$ Isto, 379-380.

${ }^{40}$ Isto, 401-403.
} 
četnici polagati pravo na to da su oni u zemlji uspostavili red, pošto Nemci nisu to bili u stanju da urade"." ${ }^{41}$

Tokom septembra, i pored svega, postojale su nemačke dileme o uključivanju ,pouzdanih“" Pećančevih snaga u ,pomoćnu žandarmeriju“. U ovom periodu, sudeći po komunikaciji Feldkomandanture i banske uprave u Nišu, odlučeno je da se formiraju vojnički četnički odredi, koje će kao žandarmerijske snage „u svakom pogledu preuzeti srpska vlada“. Ova Feldkomandantura je tražila adekvatan prostor za uži štab Koste Pećanca, ,a gde će on i stanovati, pošto će ubuduće često boraviti ovde". Prema stavu koji je iznela Feldkomandantura, trebalo je da četnici zamene ove predviđene a neformirane trupe. ${ }^{42}$ Nemci su napustili oblast Toplice i predali je Kosti Pećancu i njegovim snagama na kontrolu, gde je jedan deo njih ušao u pojedina mesta ove oblasti. ${ }^{43}$

Četničke snage koje su se stavile na raspolaganje Vladi imale su prve borbe sa partizanima u Toplici (njihovi odredi nosili su imena srezova ili lokaliteta na kojima su bili obrazovani, i po tome se nisu razlikovali od drugih ustanika). Prvi takav sukob, prema pisanju lista Novo vreme, izbio je u selu Draguši 17/18. septembra. Potom, 18. septembra u selu Rudna Glava kod Majdanpeka snage vojvode Anđelka napale su lokalni partizanski odred. Pećančeve snage i žandarmi zajednički su se suprotstavili partizanskim snagama u Bajinoj Bašti. ${ }^{44}$

Kako su se u rejonu zapadno od Leskovca Pećančeve snage našle u međusobnom raskolu, došlo je do partizanske akcije već od noći 8/9. oktobra u napadu na Lebane i zatim na četnike Krste Mihajlovića, vojvode jablaničkog, u Lapotincu. Potom je 14. oktobra sa Krajskomandanturom u Leskovcu dogovoreno da se njegove snage održavaju na prostoru Jablanice i Puste Reke. ${ }^{45}$ Pećančeve snage su posle toga krenule u akciju na komuniste oko Leskovca i Vlasotinca, gde su preuzele vlast na određeno vreme.

Posebno su efikasne bile četničke snage u istočnoj Srbiji protiv komunističkih snaga u više akcija od 29. septembra do 5. oktobra, gde su zajedno nastupali oružani odred iz Knjaževca, Krajinski, Borski i Zaglavski četnički odred. Posle značajnih gubitaka, partizani su proterani do daljeg iz ove oblasti. ${ }^{46}$

Deo Pećančevih četničkih snaga nije želeo da pristupi Vladinim snagama i nastavio je ustaničku akciju. Usled ustaničkog zamaha, Pećančev ugled u javnosti je posle objavljivanja Proglasa još više opao, a tome su doprineli neaktivnost $i$ nejasan stav njegovih odreda na terenu. Za razliku od komunista ili vojnih četnika, u Pećančevoj organizaciji započeo je u ovom periodu proces polarizacije.

Tokom septembra, kako se ustanak rasplamsavao, neki od Pećančevih ljudi kao što su bili aktivni oficiri Keserovići i Radojević ili rezervni Nikola Ka-

\footnotetext{
${ }^{41}$ Zbornik, tom 12, knjiga 2, 1010-1011.

${ }^{42}$ Zbornik 12-1, 517-518.

${ }^{43}$ М. Младеновић, н. д., 214 (И. Ивановић, Напомена приређивача).

${ }^{44}$ Ново време, 18, 19. и 23. септембар 1941.

${ }^{45}$ М. Павловић, Б. Младеновић, н. д., 226-230.

${ }^{46}$ Д. Петровић, н. н., 199.
} 
labić, prešli su na stranu pukovnika Mihailovića. Naime, na terenu istočno od Kruševca potpukovnik Radojević je imao sporazum sa lokalnim komunističkim snagama; 23. septembra on je krenuo u borbu protiv okupatora. Radojević je kao oficir shvatao da predvodi širi nacionalni pokret pa je u svoje redove pozivao i komunističke pristalice, ali i predstavnike vlasti, pre svega žandarmeriju. Tako je od komandira žandarmerijske čete u Velikom Šiljegovcu tražio da ljudstvo sa oružjem pređe Stalaćkom četničkom odredu. Slično je postupao i kapetan Keserović u rejonu Kruševca. Objedinjene snage Keserovićevih četnika i partizana pokušale su 23-24. septembra da uđu u Kruševac, ali je napad propao uz veće gubitke na obe strane, i zbog neslaganja i neusklađenosti napadača (neki autori ukazuju na netrpeljivost Keserovića i Radojevića, itd.). Nemcima je pristiglo i pojačanje. Deo četničkih snaga koje nisu uspele da stignu u napad (Gočki četnički odred) ostao je veran Pećancu. Ubrzo, oko 500 njihovih četnika je raspoređeno u grad. U toku borbe oko grada, Pećanac se založio da se napad suzbije i prekine savezništvo četnika i partizana. Prvo naredbom od 23. septembra, a potom i apelom srpskom narodu od 24. septembra, on je nastupio protiv sopstvenih snaga koje su sa partizanima napale Kruševac. Protivrečna naređenja Pećanca (delom i generala Novakovića) izazvala su pometnju kod četnika u tom delu Srbije. Obojica oficira su izdala proglas javnosti u kojem su iskazali protivljenje bratoubilačkoj borbi i objavili da ustaju „u borbu za slobodu, za Otadžbinu protivu okupatora i njihovih slugu“. Oni su kao izdajnike napali Pećanca i Nedića i pozvali narod da masovno pristupa „nacionalno-oslobodilačkim četničkim odredima“. Pećanac je ovu dvojicu osudio na smrt, kao i neke od partizanskih vođa.

Septembarske ustaničke dane general Ljubo Novaković je iskoristio za povod da se stavi na čelo Pećančevih odreda u svojoj okolini, kojima je razaslao poziv na ustanak. Novaković je u zoni gde se kretao pokušavao da stvori veću organizaciju i tada se definitivno okrenuo borbi protiv Nemaca. Protiveći se vojnočetničkoj organizaciji Mihailovića, paktirao je sa partizanskim snagama. Posle ovoga istupa, Kosta Pećanac ga je 20. septembra smenio i „odjurio od sebe“. Nakon nekoliko bombastičnih naređenja o napadu na Kragujevac, pa čak i Beograd, sa preostalim ljudima (vojvodama) Novaković se povukao u zonu oko Kruševca. Komandant Trstenika, u to vreme vojvoda ljubostinjski, piše 26. septembra „zahvaljujući se Bogu“ što je obustavio borbu povodeći se za naređenjem Novakovića i susednih vojvoda. Sedmog oktobra Keserović, Radojević, potom general Novaković, ali i partizani, ukupno oko 120 ljudi, ušli su u Aleksandrovac. Pet dana kasnije, 12. oktobra, četničke snage Koste Pećanca pod komandom vojvode Rode zauzele su to mesto u kome su bile ,nacionalnooslobodilačke četničke" snage. Potom su se Keserović i Radojević povukli na Kopaonik i priključili se vojno-četničkim snagama, a general Novaković se kasnije priključio partizanima. ${ }^{47}$

${ }^{47}$ AVII, k. 33, f. 13, d. 10, 14, 25; Isto, k. 33, f. 11, d. 21; Д. Петровић, н. н., 197-198; J. Ђиновски, н. н,. 225-230; Кузман Николић, Збивања међу четницима у крушевачком крају 
Pojedine Pećančeve vojvode su figurirali sa svojim odredima kao nezavisni, sarađujući na terenu sa partizanima. Takvi su bili: Jovan Škava i Mašan Đurović u zapadnoj Srbiji, Leonida Plješković, Anđelko Krajinski i Voja Tribrođanin u istočnoj Srbiji. Pojedini, kao Boža Matić ili Milorad Radić - Pinda u valjevskom kraju, ostali su neaktivni, ali su u narednom periodu krenuli u borbu protiv ustanika kao deo oružanih snaga Vlade generala Nedića.

Septembar 1941. označava definitivnu prekretnicu u opredeljenjima dva nacionalna pokreta otpora (gerilske organizacije) prema ustanku i borbi sa okupatorskim snagama. Vojno-četnički odredi pukovnika Mihailovića stali su na stanovište aktivnog otpora, odbili koordinaciju aktivnosti sa Nedićevom Vladom i uključili se u borbe zajedno sa komunističkim (partizanskim) grupama. Četnička organizacija Koste Pećanca doživela je delimičnu diferencijaciju, ali je njen najveći deo stao na stranu Vlade generala Nedića i nemačkog vojno-okupacionog aparata i aktivno se uključio u borbe protiv ustanika.

Bojan B. Dimitrijević

\section{THE EMERGENCE OF THE NATIONAL RESISTANCE MOVEMENTS IN OCCUPIED SERBIA 1941}

\section{Summary}

The article provides an account to emergence of the national resistance movements in occupied Serbia 1941. Two organisations were present. The remnants of the Yugoslav Army, which refused to accept the act of capitulation and to surrender their arms, led by the Colonel Dragoljub Mihailović. And the other one: the Chetnik organisation led by the First World War resistance hero and reserve officer Kosta Pećanac. After the creation of the Serbian government with General Milan Nedić in early September 1941, their officials followed Nedić's instructions to establish the contact with national resistance groups. The main effort was to stop the Communist action, which caused brutal German reprisals. But unfortunately, those efforts led to the firm division between the Mihailović military organisation which maintained the inheritance of the pre-army and the Nedić government.

On the other side, Pećanac Chetnik organisation, after the differentiation in some areas, joined the Nedić's government side, and German occupation apparatus, and started to fight against the Communist and Mihailović's resisters.

пре напад на Крушевиа сетпембра 1941. године, Расински анали, 4/2006, 55-68. U Nikolićevom tekstu data je detaljnija analiza odnosa Keserovića, Radojevića i Pećančeve organizacije. - Добривоје Секуловић Малиша, Жупа у народоослободилачкој борби 1941-1945, Александровац 1995. 